\title{
HYDROXYAPATITE AND PORPHYRIN-FULLERENE NANOPARTICLES FOR DIAGNOSTIC AND THERAPEUTIC DELIVERY OF PARAMAGNETIC IONS AND RADIONUCLIDES
}

\author{
Orlova MA ${ }^{1,2}$, Nikolaev $\mathrm{AL}^{1}$, Trofimova $\mathrm{TP}^{1,3}$, Orlov $\mathrm{AP}^{1}$, Severin $\mathrm{AV}^{1}$, Kalmykov $\mathrm{SN}^{1}$ \\ Faculty of Chemistry, Lomonosov Moscow State University, Moscow \\ Department of Biochemistry and Pharmacology, \\ Dmitry Rogachev National Medical Research Centre of Hematology, Oncology and Immunology, Moscow \\ ${ }^{3}$ Institute of Physiological Active Compounds of RAS, Chernogolovka
}

\begin{abstract}
Nanoparticles for drug delivery are the subject of extensive research. Importantly, they can transform in size during synthesis or actual use, thereby changing their cytotoxic properties. The aim of the present work was to study the tendency of [ ${ }^{67} \mathrm{Zn}$ ] porphyrin-fullerene nanoparticles (BFNP) to aggregate over time and to compare the properties of hydroxyapatite (HAP) nanoparticles obtained through 3 different techniques. We found that aggregation of BFNP nanoparticles does not affect their function but attenuates their cytotoxicity against leukemia cells. We were also able to obtain HAP nanoparticles with programmable properties (such as size, shape or the capacity to adsorb metal ions, ligands and chemical complexes) through enzymatic synthesis by varying its conditions. The synthesized HAP nanoparticles contain short-lived isotopes of zinc and copper (in the form of ions and complexes with pyrimidine or thiazine derivatives). These tumoricidal components (a radionuclide and a ligand or a complex) determine the diagnostic and therapeutic potential of the obtained radiopharmaceutical agents.
\end{abstract}

Keywords: hydroxyapatite, porphyrin-fullerene, thiazine and pyrimidine derivatives, HL-60, K-562, MOLT-4, zinc and copper radionuclides

$\triangle$ Correspondence should be addressed: Marina A. Orlova

Leninskie gory 1, bl. 3, Moscow, 119992; orlova.radiochem@mail.ru

Received: 27.06.2018 Accepted: 20.09.2018

DOI: $10.24075 /$ brsmu.2018.075

\section{НАНОЧАСТИЦЫ НА ОСНОВЕ ГИДРОКСИАПАТИТА И ПОРФИРИНФУЛЛЕРЕНА ДЛЯ ДИАГНОСТИЧЕСКОГО И ТЕРАПЕВТИЧЕСКОГО ПРИМЕНЕНИЯ ПАРАМАГНИТНЫХ ИОНОВ И РАДИОНУКЛИДОВ}

\author{
М. А. Орлова ${ }^{1,2}$, А. Л. Николаев ${ }^{1}$, Т. П. Трофимова ${ }^{1,3}$, А. П. Орлов ${ }^{1}$, А. В. Северин ${ }^{1}$, С. Н. Калмыков $^{1}$ \\ Химический факультет, Московский государственный университет имени М. В. Ломоносова, Москва \\ Отдел биохимии и фармакологии, \\ Национальный медицинский исследовательский центр детской гематологии, онкологии и иммунологии имени Д. Рогачева, Москва \\ ${ }^{3}$ Институт физиологически активных веществ РАН, Черноголовка
}

\begin{abstract}
Использование наночастиц как носителей лекарственных средств широко изучается. Одним из важных вопросов остается изменение размеров и цитотоксических свойств частиц в процессе их получения и применения. Целью работы было исследовать возможную агрегацию [ $\left.{ }^{67} \mathrm{Zn}\right]$ порфириннфуллерен-наночастиц (BFNP) в зависимости от времени и провести сравнительный анализ свойств наночастиц гидроксиапатита (НАР), полученных различными способами. Оказалось, что агрегация BFNP качественно не влияет на функцию наночастиц, но количественно уменьшает их воздействие на лейкемические клетки. Варьирование способов получения и обработки наночастиц НАР позволяет менять их форму, размеры и сорбционную способность по отношению к ионам металлов, а также лигандам и комплексам. Используя ферментативный метод, мы получили НАР с заранее заданными свойствами путем варьирования условий синтеза. Полученные наночастицы НАР представляют собой радиопрепараты, содержащие короткоживущие изотопы цинка и меди (в виде ионов и соединений - производных тиазина и пиримидина). Эти наноконструкции содержат два антиопухолевых компонента (радионуклид и лиганд или комплекс), что определяет их фармакологический потенциал для диагностики и лучевой терапии.
\end{abstract}

Ключевые слова: гидроксиапатит, порфиринфуллерен, производные тиазина и пиримидина, HL-60, K-562, MOLT-4, радионуклиды цинка и меди

$\bigotimes$ Для корреспонденции: Марина Алексеевна Орлова Ленинские горы, д. 1, стр. 3, г. Москва, 119992; orlova.radiochem@mail.ru

Статья получена: 27.06.2018 Статья принята к печати: 20.09.2018

DOI: 10.24075 /vrgmu.2018.075

The evolution of contemporary medicine prompts researchers to seek new approaches to drug design and administration, especially when it comes to highly toxic tumoricidal agents whose delivery to a biological target must be strictly precise.
Attention is increasingly paid to monoclonal antibodies [1], biological transporters [2], nanostructures and nanoplatforms. Especially worth mentioning are such carriers as fullerenes [3], nanodiamonds [4], inorganic nanoparticles of different nature 
[5, 6], liposomes [7], nanoporous silicon [8], and hydroxyapatites (HAP) [9]. There are a few important goals that novel drug delivery systems are intended to achieve. First, they are expected to reduce the toxic effect of a carried drug on healthy organs and tissues. A good example here is doxil, the liposomal formulation of doxorubicin [10], Second, they can enhance the tumoricidal effect through the synergy of the drug/carrier complex [11]. For example, synthetic Buckminsterfullerene $\left(\mathrm{C}_{60}\right)$-2-(butadiene1-yl)-tetra(o-y-aminobutyryl-o-phthalyl) porphyrin (BFNP) nanoparticles can be used to deliver magnetic isotopes ${ }^{25} \mathrm{Mg}$ and ${ }^{67} \mathrm{Zn}$, which have a biological activity of their own. Such complexes can alleviate metabolic acidosis induced by postchemotherapy hypoxia [12]. Third, drug delivery systems aim to increase the bioavailability of the drug (which can be done by using, say, albumin as a carrier), ensure its sustained release (nanofullerenes, HAP) and enhance the tumoricidal effect by binding to the target specifically (monoclonal antibodies). Fourth, a carrier and a drug constituting a delivery system can have different tumoricidal effects. For example, fullerene derivatives capable of killing cancer cells are used as carriers of magnetic isotopes or radionuclides [13]. This principle is employed in designing radiopharmaceuticals for anticancer radiation therapy.

HAP nanoparticles are attractive drug and radionuclide carriers due to their biodegradability, biocompatibility and bioresorbability. These qualities are determined by their calciumphosphate origin, which mimics the chemical composition of the human bone mineral fraction [14, 15].

The aim of this work was to study the properties of HAP obtained through different methods of synthesis (and therefore exhibiting different properties) and BFNP in relation to their use as bioactive metal ion carriers, including radionuclides, and ligands with tumoricidal activity.

\section{METHODS}

\section{Zinc complexes}

The N(5,6-dihydro-4H-1,3-thiazine-2-yl)benzamide $\left(L^{1}\right)$ ligand in the form of $\mathrm{L}^{1} \mathrm{HBr}$ was synthesized following a previously described technique [16]. To obtain the $\mathrm{L}^{1} \mathrm{ZnCl}_{2}\left(\mathrm{C}^{1}\right)$ complex,<smiles>O=C(NC1=NCCCS1)c1ccccc1</smiles>

$\left(L^{1}\right)$

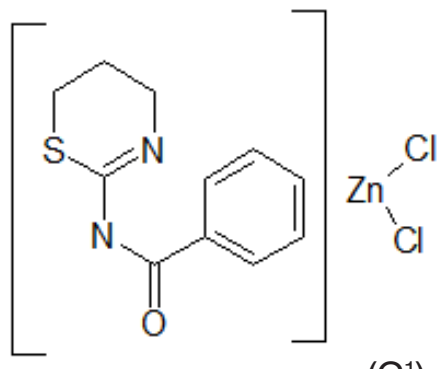

$\left(\mathrm{C}^{1}\right)$
$\mathrm{L}^{1} \mathrm{HBr}$ in the aqueous solution was converted to its basic form in the presence of $\mathrm{NaOH}$ (Fig. 1). A solution of zinc chloride in diethyl ether at a ratio of $1: 1$ was gradually added to the $L^{1}$ base in diethyl ether. The solution was stirred for $0.5 \mathrm{~h}$. The white crystalline precipitate was separated and washed with ether. The reaction yield was $64 \%$. Ligand $\mathrm{L}^{2}$ was 2 -aminopyrimidine (Sigma; USA), ligand $L^{3}$ was 2-aminopyrimidine salicylate. Their complexes with zinc $\mathrm{Zn}\left(\mathrm{L}^{2}\right)_{2} \mathrm{Cl}_{2}\left(\mathrm{C}^{2}\right)$ and $\mathrm{Zn}\left(\mathrm{L}^{3}\right)_{2}\left(\mathrm{C}^{3}\right)$ were obtained as described in [17]. The composition of all complexes was characterized by element analysis and ${ }^{1} \mathrm{H}-\mathrm{NMR}$ (Bruker CXP-200 spectrometer; Germany).

\section{Spectrophotometry}

Spectrophotometry was performed using the UV-1280 spectrophotometer (Shimadzu; Japan). Calibration curves were constructed for the ligands and the complexes in the aqueous, physiological saline and alcohol solutions.

\section{Protonation and stability constants}

The constants were determined by potentiometry using the automatic titrator Metrohm 848 Titrino plus (Metrohm AG: Switzerland). The stability constant was measured using the glass electrode. Computations were done in Hyperquad 2013.

\section{HAP synthesis}

Coprecipitation. There are different methods of HAP synthesis [18-20] producing end products with different parameters. We synthesized $\mathrm{HAP}_{1}$ at room temperature using the stoichiometric $\mathrm{Ca} / \mathrm{P}$ molar ratio of 1.67 [21]. All reagents were taken in the amount sufficient to produce a 5\% (solid mass content) suspension [22]. Trace amounts of calcium and zinc in the residual liquid were determined by inductively coupled plasma atomic emission spectroscopy (ICP-AES) on Optima 100 DV (Perkin Elmer; USA). To obtain $\mathrm{HAP}_{2}$, the suspension was continuously heated to $90^{\circ} \mathrm{C}$ without boiling for $4 \mathrm{~h}$.

Enzymatic hydrolysis. $\mathrm{HAP}_{\mathrm{E}}$ was synthesized through the enzymatic hydrolysis of calcium glycerophosphate in the presence of alkaline phosphatase (Merck; Germany). Reaction
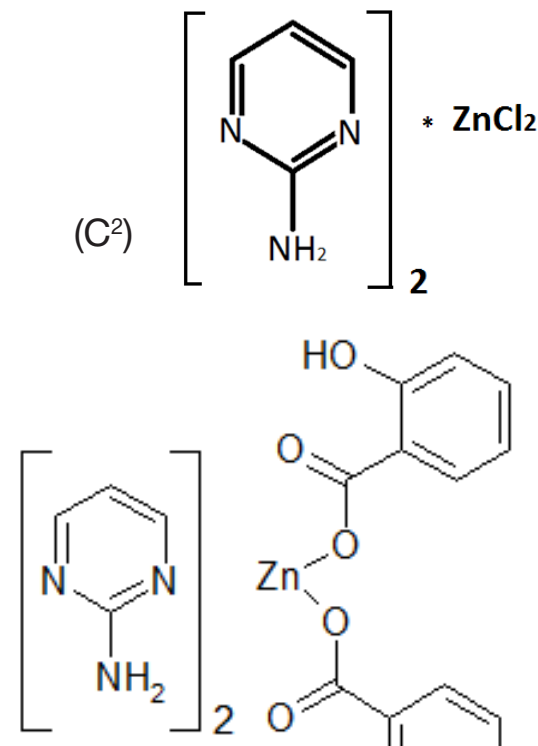<smiles>[Z7]OC(=O)c1ccccc1C(=O)O[Z17](=O)OC(=O)c1ccccc1O</smiles>

$\left(C^{3}\right)$

Fig. 1. The structural formula of the compounds used in the present study 
conditions were varied, including the enzyme concertation, the medium (water, glycerol buffer, tris buffer), $\mathrm{pH}$ (7 to 10), calcium concentration and the reaction time. The glycerophosphate hydrolysis reaction was triggered by adding the enzyme solution to the calcium glycerophosphate solution taken at a concentration of $0.02 \mathrm{~mol} / \mathrm{l}$. Working concentrations of the enzyme ranged from 0.02 to $0.4 \mu \mathrm{g} / \mathrm{ml}$. Depending on the conditions, the reaction time was varied between a few hours and a few days.

Introduction of zinc and copper ions during HAP synthesis. Weighted amounts of zinc or copper oxides (chemically pure, C. P.) corresponding to the anticipated $\mathrm{Zn}(\mathrm{Cu}) / \mathrm{Ca}$ molar ratio of 5 (15 mol\%) were dissolved in $\mathrm{H}_{3} \mathrm{PO}_{4}$. The obtained solution was introduced dropwise to the suspension of $\mathrm{Ca}(\mathrm{OH})_{2}$ under continuous stirring. The samples of $\mathrm{HAP}_{\mathrm{zn} 1}, \mathrm{HAP}_{\mathrm{zn} 2}$ and $\mathrm{HAP}_{\mathrm{Cu}}$ were obtained. Some of those samples were dried, annealed in a muffle furnace in air at $900{ }^{\circ} \mathrm{C}$ for $3 \mathrm{~h}$ and subsequently studied with XPA (see below).

\section{Electron microscopy of HAP samples}

Some of the samples were sonicated in a sonic bath for $30 \mathrm{~s}$ at $22 \mathrm{kHz}$ frequency and $50 \mathrm{~W}$ power. The samples were prepared for microscopy using a standard technique and then inspected under the JSM-6380LA microscope (JEOL; Japan) at the accelerating voltage of $20 \mathrm{kV}$.

\section{Metal nuclides}

69m Zn $\left(T_{1 / 2}=13.7 \mathrm{~h} ; \mathrm{E}_{\mathrm{y}}=438.7 \mathrm{keV}\right)$ was produced by the photonuclear reaction ${ }^{71} \mathrm{Ga}(\mathrm{y}, \mathrm{np})^{69 \mathrm{~m}} \mathrm{Zn}$ as described in [21]. To obtain a labeled compound, a reaction of isotope exchange was carried out between the $\mathrm{C}^{1}$ complex in physiological saline and ethanol solutions (1:1) and a concentrated solution of carrier-free ${ }^{69 m} \mathrm{Zn}$ eluted from a chromatography column. To obtain labeled $\mathrm{C}^{2}$ and $\mathrm{C}^{3}$ complexes, the ligands in the basic form were treated with ${ }^{69 m} \mathrm{ZnCl}_{2}$ solution under continuous stirring and heating.

${ }^{64,67} \mathrm{Cu}\left(\mathrm{T}_{1 / 2}=12.7 \mathrm{~h}\right.$ and $61.8 \mathrm{~h}$, respectively; $\mathrm{E}_{\mathrm{y}}\left({ }^{64} \mathrm{Cu}\right)=$ $\left.1345.8 \mathrm{keV}, \mathrm{E}_{\mathrm{y}}\left({ }^{67} \mathrm{Cu}\right)=184.5 \mathrm{keV}\right)$ was produced by the reaction ${ }^{\text {natZn }}(\mathrm{y}, \mathrm{np}){ }^{64} \mathrm{Cu}$; ${ }^{\text {natZn }} \mathrm{n}(\mathrm{n}, \beta)^{67} \mathrm{Cu}$. Copper was separated from zinc by extraction in the $0.001 \%$ dithizone solution in $\mathrm{CCl}_{4}$ followed by re-execration in $6 \mathrm{M} \mathrm{HCl}$ and ion-exchange chromatography in the column with Cu-Resin (Triskem; France). Radioactivity of the reaction products was measured using a gamma-ray spectrometer with the GC 3020 HPGE detector (Canberra; USA). ${ }^{67} \mathrm{Zn}$ and ${ }^{25} \mathrm{Mg}$ (Isotope; Russia) are stable isotopes with $\mathrm{s}$ of $-5 / 2$ and $+5 / 2$, respectively (enrichment in ${ }^{67} \mathrm{Zn}$ is $94.5 \%$, isotope ${ }^{25} \mathrm{Mg}$ frequency is $99.9 \%$ ).

\section{Size of nanoparticles}

Nanoparticle sizes were measured by dynamic light scattering.

\section{Thin-layer chromatography (TLC)}

For TLC we used Silufol plates with different eluents. The plates were developed with iodine vapors.

\section{Autoradiography (ARG)}

After TLC, the plates with the obtained radioactive compounds were analyzed using Cyclone Plus, the storage phosphor system

Table 1. Lethal concentrations $\left(L_{50}\right)$ of Zn-BFNP and ${ }^{67} \mathrm{Zn}$-BFNP complexes for leukemic cell lines and healthy lymphocytes depending on the nanoparticle size

\begin{tabular}{|c|c|c|c|}
\hline \multirow{2}{*}{ Complex } & \multicolumn{3}{|c|}{$\mathrm{LC}_{50}, \mu \mathrm{g} / \mathrm{ml}$} \\
\hline & B-ALL & AML & $H D^{*}$ \\
\hline Zn- BFNP & $60 \pm 8$ & $64 \pm 3$ & $81 \pm 9$ \\
\hline${ }^{67} \mathrm{Zn}-\mathrm{BFNP}$ & $16 \pm 3$ & $63 \pm 8$ & $79 \pm 9$ \\
\hline \multicolumn{4}{|c|}{ Average size of nanoparticles and $\mathrm{LC}_{50}$} \\
\hline Zn- BFNP & $25 \mathrm{~nm}$ & $55 \mathrm{~nm}$ & \\
\hline${ }^{67} \mathrm{Zn}-\mathrm{BFNP}$ & $37 \pm 3 \mu \mathrm{g} / \mathrm{ml}$ & $78 \pm 6, \mu \mathrm{g} / \mathrm{ml}$ & \\
\hline \multicolumn{4}{|c|}{ Average size of nanoparticles and $\mathrm{LC}_{50}$} \\
\hline Zn- BFNP & $50 \mathrm{~nm}$ & $80 \mathrm{~nm}$ & \\
\hline${ }^{67} \mathrm{Zn}-\mathrm{BFNP}$ & $10 \pm 2 \mu \mathrm{g} / \mathrm{ml}$ & $23 \pm 3 \mu \mathrm{g} / \mathrm{ml}$ & \\
\hline
\end{tabular}

Note: *HD — lymphocytes obtained from healthy donors.

Table 2. Survival $\left(\mathrm{LC}_{50}\right)$ of different cells in the presence of the studied zinc salts, chelators and HAPs

\begin{tabular}{|c|c|c|c|c|c|c|}
\hline \multirow{2}{*}{ Compounds } & \multicolumn{6}{|c|}{$\mathrm{LC}_{50}, \mu \mathrm{mol} / \mathrm{ml}$} \\
\hline & HD cells & K-562 & MOLT-4 & MOLT-4 (res) & HL-60 & $\mathrm{B}-\mathrm{ALL}^{*}$ \\
\hline $\mathrm{ZnCl}_{2}{ }^{* *}$ & $1.6 \pm 0.3$ & $0.52 \pm 0.05$ & & & & \\
\hline $\mathrm{ZnSal}_{2}\left(\mathrm{H}_{2} \mathrm{O}\right)_{2}{ }^{* *}$ & $0.68 \pm 0.06$ & $0.41 \pm 0.05$ & & & & \\
\hline$C^{3}$ & $1.0 \pm 0.2$ & $0.25 \pm 0.04$ & & & & \\
\hline $\mathrm{L}^{1}$ & $10.6 \pm 0.5$ & $1.0 \pm 0.3$ & & & & \\
\hline $\mathrm{C}^{1}$ & $4.5 \pm 0.4$ & $1.1 \pm 0.2$ & & & & \\
\hline $\mathrm{C}^{2}$ & $0.24 \pm 0.04$ & $0.12 \pm 0.02$ & $0.062 \pm 0.008$ & $0.040 \pm 0.009$ & $0.039 \pm 0.009$ & $0.061 \pm 0.007$ \\
\hline $\mathrm{HAP}_{1}$ & $>>5 \cdot 10^{-3} \mathrm{~mol} / \mathrm{l}$ & & $3.5 \cdot 10^{-3} \mathrm{~mol} / \mathrm{l}$ & $>5 \cdot 10^{-3} \mathrm{~mol} / \mathrm{l}$ & & \\
\hline $\mathrm{HAP}_{2}$ & $>>5 \cdot 10^{-3} \mathrm{~mol} / \mathrm{l}$ & & $4 \cdot 10^{-3} \mathrm{~mol} / \mathrm{l}$ & $>5 \cdot 10^{-3} \mathrm{~mol} / \mathrm{l}$ & & \\
\hline $\mathrm{HAP}_{\mathrm{Zn} 1}$ & $>>5 \cdot 10^{-3} \mathrm{~mol} / \mathrm{l}$ & & $>>5 \cdot 10^{-3} \mathrm{~mol} / \mathrm{l}$ & $>5 \cdot 10^{-3} \mathrm{~mol} / \mathrm{l}$ & & \\
\hline $\mathrm{HAP}_{\mathrm{Zn} 2}$ & $>>5 \cdot 10^{-3} \mathrm{~mol} / \mathrm{l}$ & & $>>5 \cdot 10^{-3} \mathrm{~mol} / \mathrm{l}$ & $6,5 \cdot 10^{-3} \mathrm{~mol} / \mathrm{l}$ & & \\
\hline $\mathrm{HAP}_{\mathrm{Cu}}$ & $>>5 \cdot 10^{-3} \mathrm{~mol} / \mathrm{l}$ & & $>>5 \cdot 10^{-3} \mathrm{~mol} / \mathrm{l}$ & $5 \cdot 10^{-3} \mathrm{~mol} / \mathrm{l}$ & & \\
\hline
\end{tabular}

Note: * — B-ALL designates BM cells of patients with B-cell acute lymphoblastic leukemia; ** — according to [17]. 
for digital ARG (Perkin Elmer; USA), and storage phosphor screens coated with BaFBr:Eu by the same manufacturer.

\section{X-ray diffraction phase analysis (XPA)}

The analysis was performed on the automated X-Ray diffractometer DRON-3 (Innoscope; Russia) with a Cu-K anode using the software supplied by the manufacturer. The size $D$ of crystallites was determined by the Sherrer equation:

$$
D_{\mathrm{HKL}}=\frac{\lambda}{\beta \cos \theta}
$$

\section{Measurements of adsorption}

Measurements were done using the ASAP 2000 analyzer (Micromeritics; USA). The specific surface area was calculated in the Micromeritics software supplied by the manufacturer.

\section{MTT-assay}

The protocol of the assay is described in [13]. The cell lines used in the present study included HL-60, K-562, MOLT-4, and MOLT-4 (res) (res. means the cells were resistant to asparaginase, one of the main drugs used in children with acute leukemia). The cells were cultured following the standard protocol. Statistical analysis included the Mann Whitney $U$ test. Each series of measurements consisted of at least 5 tests carried out in 3 replicates.

\section{Isolation of mononuclear cells from bone marrow and peripheral blood}

Bone marrow $(\mathrm{BM})$ cells collected from patients with B-cell acute lymphoblastic leukemia (B-ALL), acute myeloid leukemia (AML) and T-cell acute lymphoblastic leukemia (TALL) were kindly provided by D.Rogachev National Research Center of Pediatric Hematology, Oncology and Immunology. Blood tests demonstrated that the proportion of blast cells in the peripheral blood mononuclear fraction was at least $80 \%$.

Cell morphology was inspected under the fluorescence microscope LEICA DM6000B (Leica Microsystems; Germany) or the confocal laser scanning microscope LSM 710 (Carl Zeiss; Germany). The images were captured and saved by a digital camera.

\section{RESULTS}

\section{Relationship between the size of porphyrin-fullerene nanoparticles and their cytotoxicity}

Some findings suggest that increased aggregation of nanoparticles (in particular, fullerene-based) promotes survival leading to a rise in $\mathrm{LC}_{50}$, i.e. attenuates the cytotoxic effect of a drug [23-26]. However, there is counterevidence to that, mainly for nano $\mathrm{C}_{60}$. So, we decided to study the effect of aggregation in BFNP.

Table 1 presents data on the survival of leukemia cell lines and BM cells of untreated patients with acute leukemias in the presence of BFNP loaded with a naturally occurring zinc isotope or enriched in magnetic ${ }^{67} \mathrm{Zn}$. The table demonstrates the relationship between $\mathrm{LC}_{50}$ and the nanoparticle size. In all cases, cell survival improved with increased nanoparticle aggregation, but the specificity of the studied complexes did not change.

Sonication caused the average nanoparticle size to shrink to $15-20 \mathrm{~nm}$. However, a week after the average nanoparticle size reached 20-30 nm; 2 weeks after, 30-40 nm; one month after it was as big as 50-60 nm.

Morphological examination revealed that not only nanoparticles but also cells treated with ${ }^{67} \mathrm{Zn}$-loaded BFNP tended to aggregate increasingly (these data are not provided in the table).

\section{Effect of ligands and HAP-ligand compositions on the cells}

Both ligands and their complexes with metal ions, such as zinc or copper (which can be substituted with radionuclides to produce a radiopharmaceutical), can be regarded as potential tumoricidal chelating agents and used for HAP doping. Ligands

A

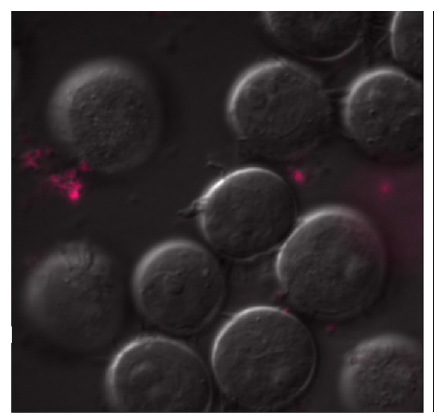

B

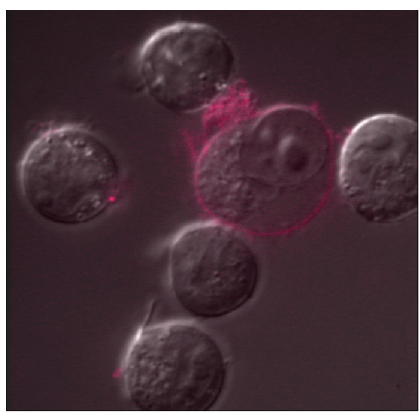

Fig. 2. MOLT-4 cells treated with $L^{3}(\mathbf{A})$ and $C^{3}(\mathbf{B})$ under the confocal laser scanning microscope

A
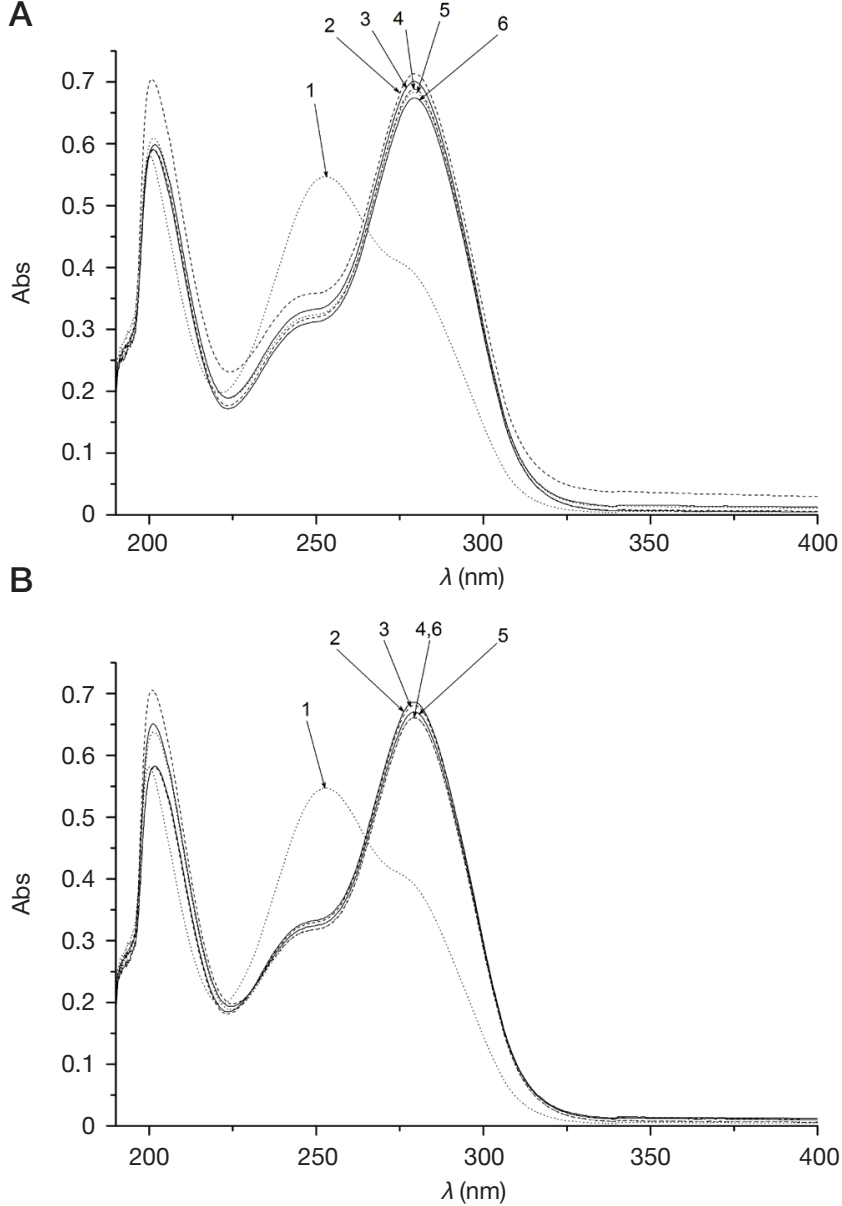

Fig. 3. Absorption spectra of $10-2 \mathrm{mg} / \mathrm{ml} \mathrm{L}^{1}$ solution that was in contact with $\mathrm{HAP}_{2}$ (A) and $\mathrm{HAP}_{1}$ (B) for $0 \mathrm{~min}$ (1), $5 \mathrm{~min}$ (2), $10 \mathrm{~min}$ (3), $15 \mathrm{~min}$ (4), $30 \mathrm{~min}$ (5), and 60 min (6) 
and metal ions can be loaded to HAP together as complexes or separately. In both cases, the complex and its components will produce either synergistic or independent effects.

Table 2 compares the survival of $\mathrm{K}-562$ cells and lymphocytes of healthy donors (HD) in the presence of $L^{1}$ and complexes. Both healthy lymphocytes and MOLT-4 и MOLT-4 (res) cells demonstrated very high survival rates when treated with different HAP samples, including those that contained zinc and copper ions.

The studied chelators and complexes displayed a tendency to increased (decreased) toxicity against healthy lymphocytes and cancer cells. The lymphocytes of healthy donors demonstrated the following pattern of survival rate decline: $\mathrm{L}^{1}>\mathrm{C}^{1}>\mathrm{ZnCl}_{2}>\mathrm{C}^{3}>\mathrm{ZnSal}_{2}\left(\mathrm{H}_{2} \mathrm{O}\right)_{2}>\mathrm{C}^{2}$. With chronic myeloid leukemia cells (K-562), the pattern changed: $C^{1}>L^{1}>$ $\mathrm{ZnCl}_{2}>\mathrm{ZnSal}_{2}\left(\mathrm{H}_{2} \mathrm{O}\right)_{2}>\mathrm{C}^{3}>\mathrm{C}^{2}$. The therapeutic window (or the therapeutic index $\mathrm{TI}=\mathrm{LC}_{50}(\mathrm{HD}) / \mathrm{LC}_{50}$ (leukemia cells)) declined in the following fashion: $\mathrm{L}^{1}>\mathrm{C}^{3} \sim \mathrm{C}^{1}>\mathrm{ZnCl}_{2}>\mathrm{C}^{2}>\mathrm{ZnSal}_{2}\left(\mathrm{H}_{2} \mathrm{O}\right)_{2}$. This leads us to conclude that all 3 studied complexes have a potential to be considered as tumoricidal agents.

When comparing the toxic effects of $\mathrm{C}^{2}$ on leukemia cell lines and BM cells obtained from patients with B-ALL, we observed the following pattern: HD cells $>$ K-562 > HL-60 MOLT-4 > MOLT-4(res) BM (B-ALL). Importantly, $\mathrm{C}^{2}$ exhibited higher toxicity towards MOLT-4 (res) than to MOLT-4 cells, meaning it has specificity to the cells with the most resistance to chemotherapy. The complexes tended to exhibit higher cytotoxicity than the ligands, perhaps due to the development of necrosis in addition to apoptosis (Fig. 2).

Stability of ligands and their complexes in aqueous/ physiological saline solutions is their important property. Unfortunately, much more common are bioactive chelating ligands and complexes that are poorly soluble. They need a special shell or a carrier to be delivered to a target. HAP meets this requirement only partly.

Spectrophotometric measurements of stability of the studied complexes in water, ethanol and physiological saline solutions revealed that $\mathrm{C}^{1}$ was the least stable complex: it tended to hydrolyze over time producing thiazine that, however, has mild tumoricidal and strong radioprotective properties.

A

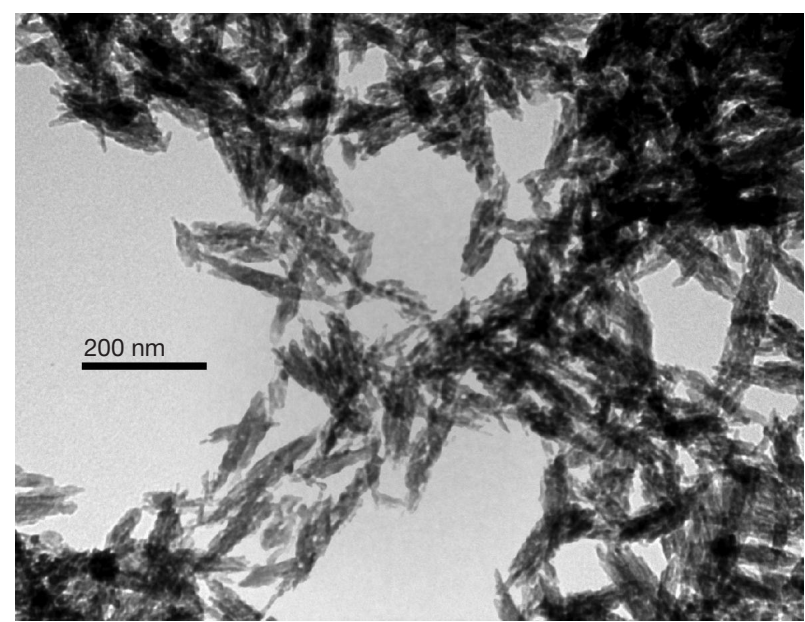

Other complexes were quite stable when dissolved, which makes them more suitable for clinical purposes.

As determined by the potentiometric titration of the ligand $\mathrm{L}^{1}$ performed in aqueous and physiological saline solutions with varying $\mathrm{pH}\left(\right.$ at $\mathrm{C}\left(\mathrm{L}^{1}\right)=1 \cdot 10^{-3} \mathrm{~mol} / \mathrm{l}, \mathrm{I}=0.15 \mathrm{NaCl}$ $\left(0.1 \mathrm{~mol} / \mathrm{I} \mathrm{KNO} \mathrm{KN}_{3}\right)$ ), the values of protonation constants (log $\left.\mathrm{K}\right)$ were $5.1 \pm 0.1$ (aqueous solutions) and $5.3 \pm 0.2$ (physiological solutions). Attempts to potentiometrically determine the stability constant of $\mathrm{C}^{1}$ failed. This might have been due to the production of zinc hydroxide that interfered with titration. For $\mathrm{C}^{2}$ the stability constant $\log \mathrm{K}\left(\mathrm{C}^{2}\right)$ was $10.4 \pm 0.5$.

\section{Behavior of nanoHAP doped with ligands, metal ions and/or complexes}

Fig. $3(A, B)$ shows sorption of the ligand $L^{1}$ by $H A P_{1}$ and $H A P_{2}$. Changes occur when sorption starts and are probably due to the interaction with calcium released as nanoHAP dissolves. It means that the ligand $L^{1}$ does not bind to hydroxyapatite. The same behavior was observed for $L^{2}$ and $L^{3}$.

The morphology of nanocrystals can be visualized using electron microscopy, while the composition of the solid phase (biohydroxyapatite) can be inferred from the results of X-ray diffraction phase analysis. For $\mathrm{HAP}_{1}$, results of these analytical modalities are presented in Fig. 4. When subjected to heating, both zinc-loaded and "pure" nanoparticles shrank in size. This transformation was considerable for "pure" samples and almost insignificant for those doped with zinc (Table 3).

The major phase of $\mathrm{HAP}_{\mathrm{E}}$ (Fig. 5A) was hydroxyapatite (Fig. 5B); $\mathrm{HAP}_{\mathrm{E}}$ nanoparticles tended to have a spherical shape and formed aggregates. The specific surface area of the studied sample determined by nitrogen absorption was $300 \mathrm{~m}^{2} / \mathrm{g}$. Pore sizes varied considerably $(2-300 \mathrm{~nm})$. The size of crystallites in the samples with crystal structure was calculated using the Sherrer equation (12-14 nm). Crystallites and aggregates significantly varied in size; their average dimensions are shown in Fig. 6.

We synthesized 6 different types of HAP: 3 without metal ions $\left(\mathrm{HAP}_{1}, \mathrm{HAP}_{2}, \mathrm{HAP}_{\mathrm{E}}\right)$ and 3 with metal ions $\left(\mathrm{HAP}_{\mathrm{Zn1}}\right.$, $\left.\mathrm{HAP}_{\mathrm{Zn} 2}, \mathrm{HAP}_{\mathrm{Cu}}\right)$. $\mathrm{HAP}_{\mathrm{E}}$ were big-sized hollow spheres that

B

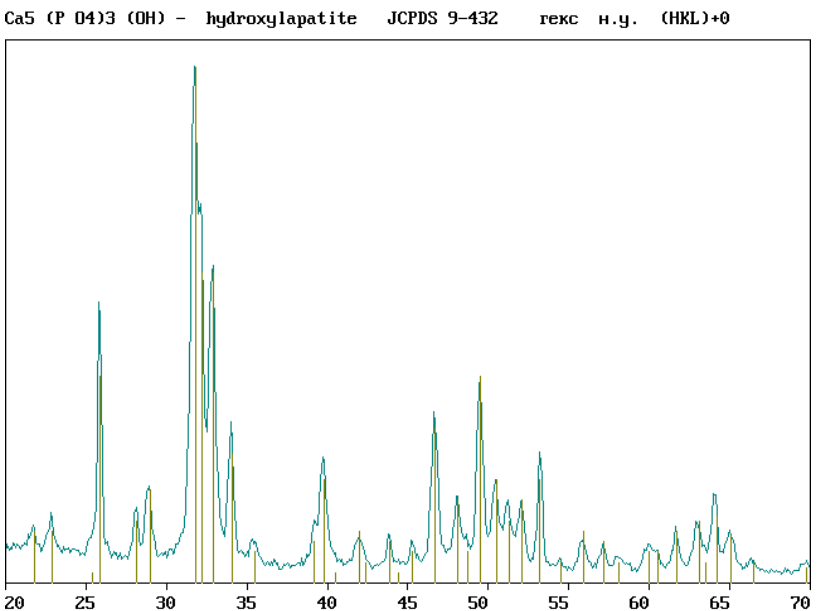

Fig. 4. Electron microscopy $(\mathbf{A})$ and $\mathrm{X}$-ray diffraction phase analysis (B) of HAP, synthesized from the suspension of calcium oxide and phosphorus acid

Table 3. Average sizes of HAP nanoparticles obtained through precipitation and HAP nanoparticles doped with zinc

\begin{tabular}{|c|c|c|c|c|}
\hline Parameter & $\mathrm{HAP}_{1}$ & $\mathrm{HAP}_{\mathrm{Zn} 1}$ & $\mathrm{HAP}_{\mathrm{Zn2}}$ & $\mathrm{HAP}_{2}$ \\
\hline Length, $\mathrm{nm}$ & $120 \pm 5$ & $110 \pm 5$ & $58 \pm 4$ & $26 \pm 2$ \\
\hline Width, $\mathrm{nm}$ & $36 \pm 3$ & $23 \pm 2$ & $19 \pm 1$ \\
\hline
\end{tabular}


A

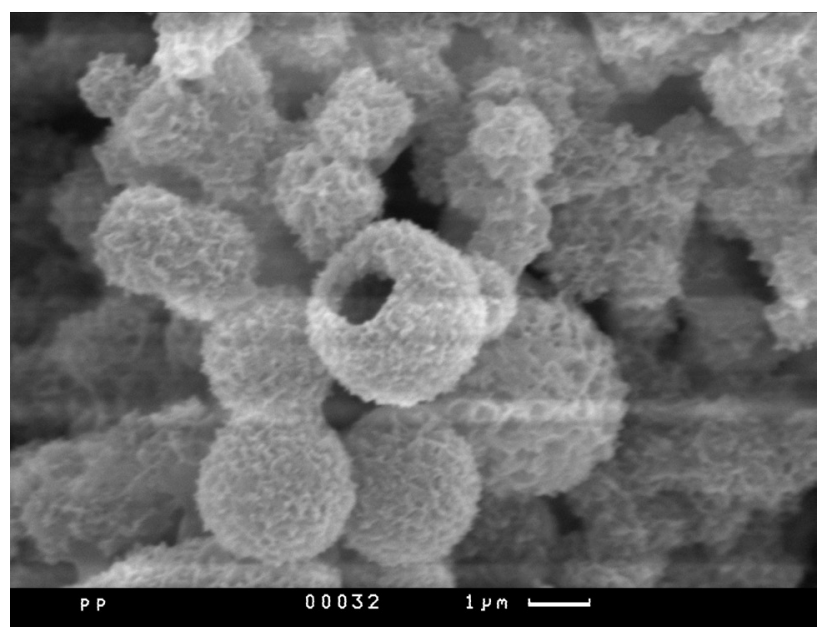

B

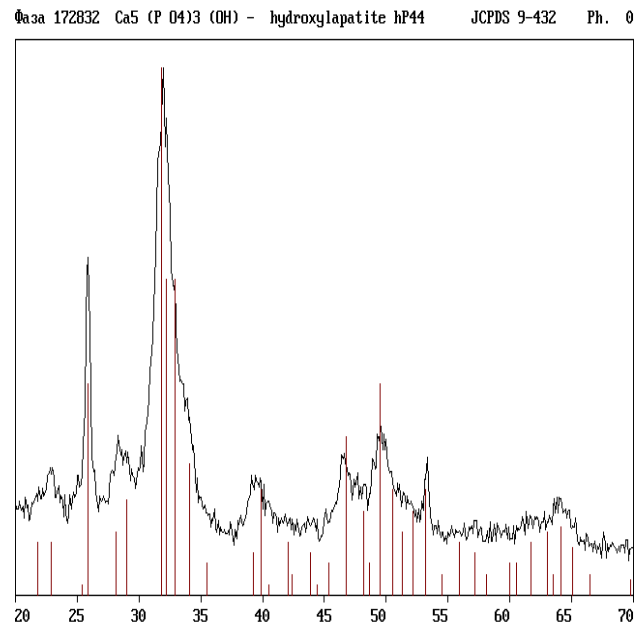

Fig. 5. Laser scanning electron microscopy (A) and X-ray diffraction phase analysis (B) of HAP $\mathrm{E}_{\mathrm{E}}$ synthesized from the aqueous solution of calcium glycerophosphate $(0.2 \mathrm{~mol} / \mathrm{l})$ at the alkaline phosphatase concertation of $0.1 \mu \mathrm{g} / \mathrm{ml}$

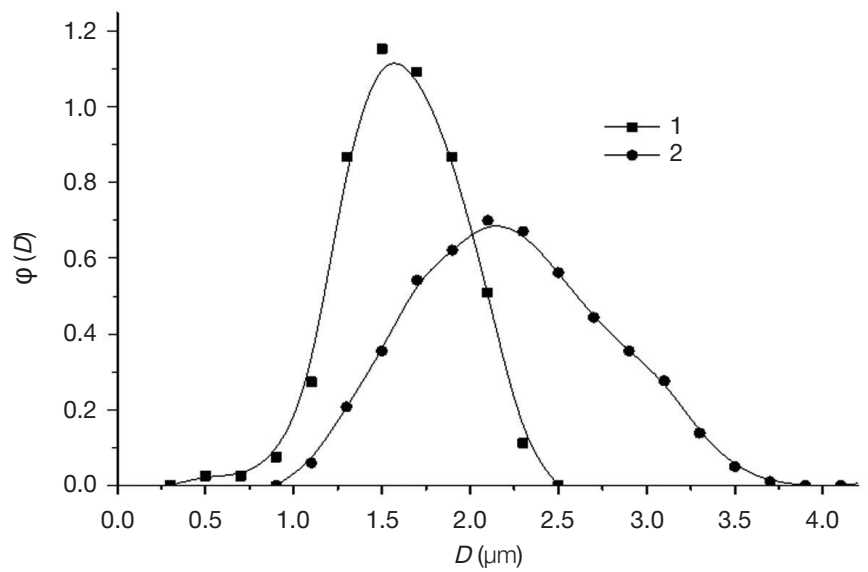

Fig. 6. Differential function of nanoparticle diameter distribution in the sample synthesized in the tris buffer $(\mathrm{pH}=9.2)$ in the presence of alkaline phosphatase taken at a concentration of: 1) $0.02 \mu \mathrm{g} / \mathrm{ml}$ (the average nanoparticle size was $1.57 \mu \mathrm{m}$ ); 2) $0.1 \mu \mathrm{g} / \mathrm{ml}$ (the average nanoparticle size was $2.22 \mu \mathrm{m}$ )

exhibited increased sorption capacity. Averages sizes of other nanoparticles were as follows: $\mathrm{HAP}_{1}>\mathrm{HAP}_{\mathrm{Zn1}}>\mathrm{HAP}_{\mathrm{Zn} 2} \sim$ $\mathrm{HAP}_{\mathrm{Cu}}>\mathrm{HAP}_{2}$.

We measured specific adsorption of zinc/copper ions by $\mathrm{HAP}_{1}$ and $\mathrm{HAP}_{\mathrm{E}}$ and calculated adsorption isotherm constants using Langmuir and Freundlich methods. Adsorption of copper ions corresponded to the Langmuir model, while adsorption of zinc ions (with equal correlation coefficients) could be described by both Langmuir and Freundlich models.

The sorption capacity of HAP towards copper ions was significantly higher than towards zinc ions. Introduction of zinc into the reaction during HAP synthesis did not seriously affect the size of nanoparticles. However, average sizes of a thermally processed $\mathrm{HAP}_{2}$ were smaller than those of $\mathrm{HAP}_{1}$. HAP particles acquired a more regular isometric shape growing in thickness, as compared to $\mathrm{HAP}_{1}$, and therefore had a smaller specific surface area. As a result, the maximum sorption capacity of $\mathrm{HAP}_{2}$ decreased.

\section{Complexes with zinc and copper radionuclides}

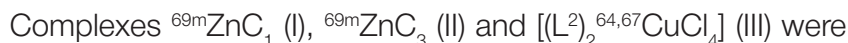
obtained through isotope exchange and analyzed by TLC, ARG and $y$-spectroscopy. The time of isotope exchange was selected experimentally to be sure that the $R_{f}$ values of radioactive complexes and those that did not contain a radionuclide were the same and also to prevent formation of side products. The obtained compounds were sorbed onto
HAP and physical and chemical measurements were then repeated. The ready pharmaceuticals had similar properties, but the copper complex disintegrated during HAP ${ }_{1}$ doping. $\mathrm{HAP}_{1}$ absorbed only copper ions. Perhaps, this problem can be solved by loading HAP with the copper complex during HAP synthesis.

\section{DISCUSSION}

Previously, it was demonstrated that the magnetic isotope ${ }^{25} \mathrm{Mg}$ (amounting to $11 \%$ in the natural isotope mixture) hyperactivates magnesium-dependent regulation of ATP synthesis, which makes the delivery of this isotope to hypoxic tissues/ cells an ambitious pharmacological task [12]. Here, BFNP nanoparticles capable of sustained release of $\mathrm{Mg}^{2+}$ and $\mathrm{Zn}^{2+}$ ions can be used as carriers. However, the major constraint for the clinical application of fullerene derivatives is their possible uncontrolled aggregation accompanied by changes in their initial cytotoxicity and physiological properties. Our study demonstrates that size transformations do not lead to critical changes in the properties of nanoparticles but attenuate their cytotoxic effect. The fundamental finding of this study is that survival of BM cells of untreated patients with B-ALL decreases 6-7-fold in the presence of ${ }^{67} \mathrm{Zn}$-BFNP, as compared to natZnBFNP. Aggregation of nanoparticles can be slowed down by sonication.

HAP nanoparticles have good prospects as drug delivery systems. There are a lot of methods for their synthesis that 
produce particles of different sizes, shapes and sorption capacity. HAP nanoparticles are also lowly toxic. Introduction of ligands and complexes into the reaction during HAP synthesis is a clever trick that helps the components of the complex to retain their properties. Enzymatic synthesis seems to be especially promising as it allows varying reaction conditions and, therefore, the parameters of the end product. This significantly expands the area of the potential application of nanoparticles.

Zinc and copper are essential micronutrients [27, 28]. They are cofactors for the majority of regulatory and antioxidant enzymes; they also are involved in DNA repair and the work of transcription factors. Complexes of short-lived zinc and copper radionuclides can be used to solve a number of diagnostic and therapeutic tasks, either simultaneously or consecutively. HAP can serve as a scaffold for a drug ensuring a synergistic sustained effect. To achieve it, a vector is needed, monoclonal antibodies being the most optimal. Importantly, HAP itself has an ability to integrate into bone tissue and become a vector. This matters in the therapy of bone and blood cancers aimed at eliminating malignant stem cells.

\section{References}

1. Karachunskie Al, Rumyantseva YuV, fon Shtakelberg A. AntiCD19 monoclonal antibody in acute lymphoblastic leukemia in children. Russ J Pediatric Hematol Oncol. 2016; 3 (4): 60-72. DOI: 10.21682/2311-1267-2016-3-4-60-72.

2. Lee $Y$, Lin $Y$, Lima $C$. Factors Controlling the Role of $Z n$ and Reactivity of Zn-bound Cysteines in Proteins: Application to Drug Target Discovery. J Chin Chem Soc. 2014; 61 (1): 142-50. DOI: 10.1002/jccs.201300392.

3. Chen Z, Ma L, Liu Y, Chen C. Applications of Functionalized Fullerenes in Tumor Theranostics. Theranostics. 2012; 2 (3): 23850. DOI: 10.7150/thno.3509.

4. Mochalin VN, Shenderova O, Ho D, Gogotsi Y. The properties and applications of nanodiamonds. Nature Nanotechnol. 2011; 7 (1): 11-23. DOI: 10.1038/nnano.2011.209.

5. Meshalkin YP, Bgatova NP. Prospects and problems of using inorganic nanoparticles in oncology. J Siber Fed Univ Biol. 2008; 3 (1): 248-68.

6. Nunes C, Estevez SV, Chantada MP. Inorganic nanoparticles in diagnosis and treatment of breast cancer. J Biol Inorg Chem. 2018; (23): 331-45. DOI: org/10.1007/s00775-018-1542-z.

7. Lasis DD, Papahadjopoulos D, editors. Medical Applications of Liposomes. USA: Elsevier Sci, 2007; 779 p. DOI: 1016/B978-0444-82917-7.X5000-5

8. Haidary SM, Corcoles EP, Ali NK. Nanoporous Silicon as Drug Delivery Systems for Cancer Therapies. J Nanomater. 2012; ID 830503:15. DOI: 10.1155/2012/830503.

9. Ferraz MP, Monteiro FJ, Manuel CM. Hydroxyapatite nanoparticles: A review of preparation methodologies. J Appl Biomater Biomechanics. 2004; 2 (2): 74-80.

10. Zhao Y, Alakhova DY, Kim JO, Bronich TK, Kabanov AV. A simple way to enhance Doxil therapy: Drug release from liposomes at the tumor site by amphiphilic block copolymer. J Control Release. 2013; 168 (1): 61-9. DOI: 10.1016/j.jconrel.2013.02.026.

11. Liu JH, Cao L, Luo PG et al. Fullerene-conjugated doxorubicin in cells. Acs Appl Mater Interf. 2010; (2): 1384-9.

12. Buchachenko AL, Kouznetsov DA, Breslavskaya NN, Orlova MA. Magnesium Isotope Effect in Enzymatic Phosphorylation. J Phys Chem. 2008; (112): 2548-56.

13. Orlova MA, Osipova EY, Roumiantsev SA. Effect of 67ZnNanoparticles on Leukemic Cells and Normal Lymphocytes. Br J Med Med Res. 2012; 2 (1): 21-30. DOl: 10.9734/ BJMMR/2012/783.

14. Sun F, Zhou H, Lee J. Various preparation methods of highly porous hydroxyapatite/polymer nanoscale biocomposites for bone regeneration. Acta Biomaterialia. 2011; 7 (11): 3813-28. DOI: 10.1016/j.actbio.2011.07.002.
In our experiments, the specific activity of the obtained radioactive agents was not high, because the experiments were preliminary and aimed to demonstrate that such complexes can be synthesized in reasonable time for the use in the clinical setting. We have sufficient resources to improve their specific activity.

\section{CONCLUSIONS}

Transformation of ${ }^{67} \mathrm{Zn}-\mathrm{BFNP}$ sizes following their aggregation does not affect their function but attenuates their cytotoxicity against leukemic cells. By applying different methods of HAP synthesis and processing, one can alter the sorption capacity of HAP towards metal ions, ligands and complexes. HAP $\mathrm{E}_{\mathrm{E}}$ with preprogrammed properties can be synthesized by varying reaction conditions. We have synthesized HAP nanoparticles containing short-lived zinc/copper isotopes in the form of ions and compounds. These nanostructures have a good potential to solve a number of diagnostic and therapeutic tasks in patients with cancer.

15. Hutmacher DW, Schantz JT, Lam CXF, Tan KC, Lim TC. State of the art and future directions of scaffold-based bone engineering from a biomaterials perspective. J Tissue Eng Regenerative Med. 2007: 1 (4): 245-60. DOl: 10.1002/term.24.

16. Orlova MA, Trofimova TP, Aliev RA, Orlov AP, Nikulin SV, Kalmykov SN et al. $69 \mathrm{mZn}$-containing radiopharmaceuticals. A novel approach to molecular design. J Radioanal Nucl Chem. 2017; 311 (2): 1177-83. DOI: 10.1007/s10967-016-5076-y.

17. Orlov AP, Orlova MA, Trofimova TP, Osipova EY, Proshin AN. Effect of salicylates and zinc salts on leukemic cells. Russ Chem Bull. 2016; 65 (7): 1879-81. DOI: 10.1007/s11172-016-1525-6.

18. Safronova EV, Putlyaev VI, Sergeeva Al, Kunenkov EV, Tretyakov YD. Synthesis of Nanocrystalline Calcium Hydroxyapatite from Calcium Saccharates and Ammonium Hydrogen Phosphate. Doklady Chem. 2009; 426 (2): 118-23. DOI: 10.1134/S0012500809060020.

19. Thian ES, Konishi T, Kawanobe Y, Lim PN, Choong C, Ho B, Aizawa M. Zinc-substituted hydroxyapatite: a biomaterial with enhanced bioactivity and antibacterial properties. J Mater Sci: Mater Med. 2013; 24 (2): 437-45. DOI: 10.1007/s10856-012-4817-X.

20. Tang Y, Chappell HF, Dove MT, Reeder RJ, Lee YJ. Zinc incorporation into hydroxylapatite. Biomaterials. 2009; 30 (15): 2864-2872. DOI: 10.1016/j.biomaterials.2009.01.043.

21. Severin AV, Pankratov DA. Synthesis of nanohydroxyapatite in the presence of iron (III) ions. Russ J Inorg Chem. 2016; 61 (1): 265-72.

22. Xu Y, Schwartz FW, Traina SJ. Sorption of Zn2+ and Cd2+ on Hydroxyapatite Surfaces. Envir Sci Technol. 1994; 28 (8): 1472-80.

23. Markovic Z, Trajkovic V. Biomedical potential of the reactive oxygen species generation and quenching by fullerenes (C60). Biomaterials, 2008; (29): 3561-73.

24. Fortner JD, Lyon DY, Sayes CM, Boyd AM, Falkner JC, Hotze EM et al. C-60 in water: nanocrystal formation and microbial response. Environ Sci Technol. 2005; (39): 4307-16.

25. Colvin VL. The potential environmental impact of engineered nanomaterials. Nat Biotechnol. 2003; (21): 1166-70.

26. Sayes CM, Gobin AM, Ausman KD, Mendez J, West J, Colvin VL. Nano-C60 cytotoxicity is due to lipid peroxidation. Biomaterials. 2005; (26): 7587-95.

27. Colvin RA, Holmes WR, Fontainea CP, Maret W. Cytosolic zinc buffering and muffling: their role in intracellular zinc homeostasis. Metallomics. 2010; 2 (2): 306-17.

28. Du Y, Guo D, Wu Q, Liu D, Bi H. Zinc Chloride Inhibits Human Lens Epithelial Cell Migration and Proliferation Involved in TGF- $\beta 1$ and TNF- $\alpha$ Signaling Pathways in HLE B-3 Cells. Biol Trace Elem Res. 2014; 159 (4): 425-43. DOl: 10.1007/s12011-014-9979-6. 


\section{Литература}

1. Karachunskie Al, Rumyantseva YuV, fon Shtakelberg A. AntiCD19 monoclonal antibody in acute lymphoblastic leukemia in children. Russ J Pediatric Hematol Oncol. 2016; 3 (4): 60-72. DOI: 10.21682/2311-1267-2016-3-4-60-72.

2. Lee $Y$, Lin $Y$, Lima C. Factors Controlling the Role of $Z n$ and Reactivity of Zn-bound Cysteines in Proteins: Application to Drug Target Discovery. J Chin Chem Soc. 2014; 61 (1): 142-50. DOI: 10.1002/jccs.201300392.

3. Chen Z, Ma L, Liu Y, Chen C. Applications of Functionalized Fullerenes in Tumor Theranostics. Theranostics. 2012; 2 (3): 23850. DOI: 10.7150/thno.3509.

4. Mochalin VN, Shenderova O, Ho D, Gogotsi Y. The properties and applications of nanodiamonds. Nature Nanotechnol. 2011; 7 (1): 11-23. DOI: 10.1038/nnano.2011.209.

5. Meshalkin YP, Bgatova NP. Prospects and problems of using inorganic nanoparticles in oncology. J Siber Fed Univ Biol. 2008; 3 (1): 248-68.

6. Nunes C, Estevez SV, Chantada MP. Inorganic nanoparticles in diagnosis and treatment of breast cancer. J Biol Inorg Chem. 2018; (23): 331-45. DOI: org/10.1007/s00775-018-1542-z.

7. Lasis DD, Papahadjopoulos D, editors. Medical Applications of Liposomes. USA: Elsevier Sci, 2007; 779 p. DOI: 1016/B978-0444-82917-7.X5000-5.

8. Haidary SM, Corcoles EP, Ali NK. Nanoporous Silicon as Drug Delivery Systems for Cancer Therapies. J Nanomater. 2012; ID 830503:15. DOI: 10.1155/2012/830503.

9. Ferraz MP, Monteiro FJ, Manuel CM. Hydroxyapatite nanoparticles: A review of preparation methodologies. J Appl Biomater Biomechanics. 2004; 2 (2): 74-80.

10. Zhao Y, Alakhova DY, Kim JO, Bronich TK, Kabanov AV. A simple way to enhance Doxil therapy: Drug release from liposomes at the tumor site by amphiphilic block copolymer. J Control Release. 2013; 168 (1): 61-9. DOI: 10.1016/j.jconrel.2013.02.026.

11. Liu JH, Cao L, Luo PG et al. Fullerene-conjugated doxorubicin in cells. Acs Appl Mater Interf. 2010; (2): 1384-9.

12. Buchachenko AL, Kouznetsov DA, Breslavskaya NN, Orlova MA. Magnesium Isotope Effect in Enzymatic Phosphorylation. J Phys Chem. 2008; (112): 2548-56.

13. Orlova MA, Osipova EY, Roumiantsev SA. Effect of 67ZnNanoparticles on Leukemic Cells and Normal Lymphocytes. Br J Med Med Res. 2012; 2 (1): 21-30. DOI: 10.9734/ BJMMR/2012/783

14. Sun F, Zhou H, Lee J. Various preparation methods of highly porous hydroxyapatite/polymer nanoscale biocomposites for bone regeneration. Acta Biomaterialia. 2011; 7 (11): 3813-28. DOI: 10.1016/j.actbio.2011.07.002.

15. Hutmacher DW, Schantz JT, Lam CXF, Tan KC, Lim TC. State of the art and future directions of scaffold-based bone engineering from a biomaterials perspective. J Tissue Eng Regenerative Med. 2007; 1 (4): 245-60. DOI: 10.1002/term.24.

16. Orlova MA, Trofimova TP, Aliev RA, Orlov AP, Nikulin SV, Kalmykov SN et al. $69 \mathrm{mZn}$-containing radiopharmaceuticals. A novel approach to molecular design. J Radioanal Nucl Chem. 2017; 311 (2): 1177-83. DOI: 10.1007/s10967-016-5076-y.

17. Орлов А. П., Орлова М. А., Трифонова Т. П., Осипова Е. Ю., Прошин А. Н. Действие салицилатов и солей цинка на лейкемические клетки. Известия АН, Серия химия. 2016; 65 (7): 1879-81. DOI: 10.1007/s11172-016-1525-6.

18. Safronova EV, Putlyaev VI, Sergeeva Al, Kunenkov EV, Tretyakov YD. Synthesis of Nanocrystalline Calcium Hydroxyapatite from Calcium Saccharates and Ammonium Hydrogen Phosphate. Doklady Chem. 2009; 426 (2): 118-23. DOI: $10.1134 /$ S0012500809060020.

19. Thian ES, Konishi T, Kawanobe Y, Lim PN, Choong C, Ho B, Aizawa M. Zinc-substituted hydroxyapatite: a biomaterial with enhanced bioactivity and antibacterial properties. J Mater Sci: Mater Med. 2013; 24 (2): 437-45. DOI: 10.1007/s10856-0124817-X.

20. Tang Y, Chappell HF, Dove MT, Reeder RJ, Lee YJ. Zinc incorporation into hydroxylapatite. Biomaterials. 2009; 30 (15): 2864-2872. DOI: 10.1016/j.biomaterials.2009.01.043.

21. Severin AV, Pankratov DA. Synthesis of nanohydroxyapatite in the presence of iron (III) ions. Russ J Inorg Chem. 2016; 61 (1): 265-72.

22. Xu Y, Schwartz FW, Traina SJ. Sorption of Zn2+ and Cd2+ on Hydroxyapatite Surfaces. Envir Sci Technol. 1994; 28 (8): 1472-80.

23. Markovic Z, Trajkovic V. Biomedical potential of the reactive oxygen species generation and quenching by fullerenes (C60). Biomaterials, 2008; (29): 3561-73.

24. Fortner JD, Lyon DY, Sayes CM, Boyd AM, Falkner JC, Hotze EM et al. C-60 in water: nanocrystal formation and microbial response. Environ Sci Technol. 2005; (39): 4307-16.

25. Colvin VL. The potential environmental impact of engineered nanomaterials. Nat Biotechnol. 2003; (21): 1166-70.

26. Sayes CM, Gobin AM, Ausman KD, Mendez J, West J, Colvin VL. Nano-C60 cytotoxicity is due to lipid peroxidation. Biomaterials. 2005; (26): 7587-95.

27. Colvin RA, Holmes WR, Fontainea CP, Maret W. Cytosolic zinc buffering and muffling: their role in intracellular zinc homeostasis. Metallomics. 2010; 2 (2): 306-17.

28. Du Y, Guo D, Wu Q, Liu D, Bi H. Zinc Chloride Inhibits Human Lens Epithelial Cell Migration and Proliferation Involved in TGF- $\beta 1$ and TNF- $\alpha$ Signaling Pathways in HLE B-3 Cells. Biol Trace Elem Res. 2014; 159 (4): 425-43. DOI: 10.1007/s12011-014-9979-6. 